\title{
Correlation between pelagic larval duration and realised dispersal: long-distance genetic connectivity between northern New Zealand and the Kermadec Islands archipelago
}

\author{
C. M. O. Reisser · J. J. Bell · J. P. A. Gardner
}

Received: 3 April 2013/Accepted: 21 September 2013/Published online: 8 October 2013

(C) Springer-Verlag Berlin Heidelberg 2013

\begin{abstract}
The extent to which marine populations are "open" (panmixia) or "closed" (self-recruitment) remains a matter of much debate, with recent reports of high levels of genetic differentiation and self-recruitment among populations of numerous species separated by short geographic. However, the interpretation of patterns of gene flow (connectivity) is often based on a stepping stone model of dispersal that can genetically homogenise even distant populations and blur genetic patterns that may better reflect realised dispersal. One way in which realised long-distance dispersal can be accurately determined is by examination of gene flow of taxa between isolated archipelagos and a mainland where there is no possible stepping stone dispersal across the open ocean. We investigated the genetic structuring of populations of the intertidal gastropod Nerita melanotragus from the subtropical Kermadec Islands and temperate New Zealand's North Island (the mainland), separated by $750 \mathrm{~km}$ of open ocean and characterised by contrasting environmental conditions. Analyses of seven microsatellite markers revealed an absence of genetic structuring with low $F_{\mathrm{ST}}$ and Jost's $D$ values (from 0.000 to 0.007 and from 0.000 to 0.015 , respectively) over large geographic distances and no evidence of isolation by distance among all populations. These results indicate that
\end{abstract}

Communicated by T. Reusch.

C. M. O. Reisser - J. J. Bell - J. P. A. Gardner

Centre for Marine Environmental and Economic Research,

School of Biological Sciences, Victoria University of

Wellington, 6140 Wellington, New Zealand

C. M. O. Reisser ( $\square)$

Unit of Ecology and Evolution, Department of Biology,

University of Fribourg, 1700 Fribourg, Switzerland

e-mail: celine.reisser@gmail.com the realised dispersal of $N$. melanotragus is of at least $750 \mathrm{~km}$, this species exhibits a very "open" form of connectivity and its larvae exhibit sufficient phenotypic plasticity to settle successfully in different environmental conditions, ranging from subtropical to cool temperate.

\section{Introduction}

One of the most fundamental debates within marine population genetics concerns the degree to which populations are "open or closed" (Swearer et al. 1999; Cowen et al. 2000; Almany et al. 2007; Shanks 2009; Pinsky et al. 2012). In an "open" population, migration (i.e. gene flow) is sufficient to generate low or non-detectable levels of genetic differentiation between the source and the receiving populations. In contrast, in a "closed" population, migration is insufficient to promote genetic homogeneity, leaving the populations genetically differentiated from each other (Cowen et al. 2000; Cowen and Sponaugle 2009). Early research on marine connectivity considered most populations to be open because of the continuous fluid nature of the oceans and life history characteristics of many marine organisms. In particular, the presence of a dispersive larval stage for most taxa and/or adults with great capacity to move was believed to promote migration among populations, with larvae and spores transported many kilometres away from their natal sites (Scheltema 1986). As a result, all new recruits were often considered to be immigrants (e.g. Tracey et al. 1975). However, recent research has provided examples of barriers to gene flow and population differentiation at scales of only a few kilometres, leading to the conclusion that marine populations may not be as "open" as previously thought (Bell and Okamura 2005; Wood and Gardner 2007; Nunes et al. 
2009; Crandall et al. 2012; Wei et al. 2013 and references therein).

The distance and the number of larvae that actually disperse away from their natal area, then survive, settle and reproduce in a new population are challenging to estimate because they depend on a variety of interconnected biologic and physical factors. The pelagic duration and feeding mode of larvae were for a long time considered to be proxies for dispersal distances achieved by a species (Scheltema 1986). Dispersal capacity integrates larval physiology, adult biology, life history and the physical characteristics of the surrounding environment to estimate the distance that larvae may disperse. This estimation is made regardless of the presence of suitable adult habitat or the recruitment and settlement success of the larvae, their subsequent growth and their reproduction in the new population (Johnson and Black 2006; Shanks 2009; Reisser et al. 2011; Wei et al. 2013). Indeed, the fitness of settling larvae may be reduced because of an extended time spent in the nutrient-poor open sea (Morgan 1995). Also, new recruits may experience increased genotype-dependent mortality compared to the self-recruited larvae because they are not adapted to the local environmental conditions (e.g. Koehn et al. 1980; Hilbish et al. 1982). In contrast, the concept of realised dispersal considers that larvae that settle in the new population must, by definition, survive and go on to reproduce with local individuals for a dispersal event to be considered successful. As such, realised dispersal is much more biologically meaningful than dispersal capacity because it accounts for the forces that can reduce or prevent gene exchange among populations at different stages of the life cycle, from larvae to adults. Whilst genetic markers are commonly used to estimate the dispersal of a species and levels of genetic differentiation among populations (e.g. Paetkau et al. 2004; Piry et al. 2004; Manel et al. 2005; Excoffier and Lischer 2010), estimating the true realised dispersal may be impossible because genetic homogeneity is not always due to the realised dispersal between populations. For example, two distant populations may be genetically connected via intermediate areas of suitable adult habitat (stepping stones) that provide generational layovers between numerous dispersal events (Crandall et al. 2012). Thus, genes from one population can "hop" and spread from one area to another in a sequential manner in time and space, leading to genetic homogeneity among sites that are geographically distant (Crandall et al. 2012; Pinsky et al. 2012). Hence, with stepping stone dispersal, the genetic variation among populations of a species might not be representative of its realised dispersal (Pineda et al. 2008; Weersing and Toonen 2009). The only way to assess whether genetic homogeneity is due to realised or stepping stone dispersal is to ensure that no suitable adult habitat occurs between populations. This is hard to test for most species because of the mosaic of habitat complexity that comprises the coastal zone and which facilitates the stepping stone model of dispersal for many taxa. However, one particular system can be used as the perfect study site for measuring effectively realised dispersal: oceanic island archipelagos.

Oceanic islands of volcanic origin are not part of continental shelf areas and have never been connected to a continent. Therefore, species occurring on such islands have originated from the dispersal of distant populations, as opposed to being derived from an ancestral presence before the physical break up of landmasses. Furthermore, geographic (and temporal) isolation of populations on offshore islands may give rise to modified life history characteristics that are adapted to local conditions (Strathmann et al. 2002). This can ultimately result in the formation of new species (Wood and Gardner 2007; Reisser et al. 2011). Because many kilometres of open sea with no suitable adult habitat can separate an oceanic archipelago from the closest landmass, the stepping stone model of dispersal is unlikely, if not impossible, to occur. Thus, measures of gene flow between an oceanic island population and its closest mainland population are unlikely to be biased by stepping stone dispersal and can provide a biologically meaningful estimate of the "true" realised dispersal of the species.

In this study, we investigated the genetic diversity, genetic structuring and levels of genetic connectivity of Nerita melanotragus, an intertidal marine gastropod, occurring at the remote Kermadec Islands and on the North Island coasts of New Zealand. The two landmasses are separated by $\sim 750 \mathrm{~km}$ of open sea (Fig. 1). Nerita is a genus of widely occurring snails (Neritidae, Gastropoda, Mollusca) found mainly on tropical and subtropical coasts, but with a few species, including $N$. melanotragus, occurring in temperate regions (Frey and Vermeij 2008). $N$. melanotragus, also known as the black nerite, has a pelagic larval duration (PLD) of 5-6 months (Waters et al. 2005), which makes it an ideal candidate to test realised dispersal versus stepping stone dispersal between populations separated by a wide expense of open ocean. $N$. melanotragus occurs on the intertidal rocky shores of eastern Australia, Lord Howe Island, Norfolk Island, northern New Zealand and the Kermadec Islands.

In this study, our aims were to estimate the extent of realised dispersal in $N$. melanotragus and to test for the impact of stepping stone dispersal on genetic structuring among populations. We thus investigated the levels of population connectivity and genetic structuring at three different spatial scales: (1) populations within the Kermadec Islands, separated by $0.7-15 \mathrm{~km}$ of sea with potential for stepping stone dispersal, (2) populations within New Zealand's North Island, separated by $14-1,100 \mathrm{~km}$ of coastal habitat with potential for stepping stone dispersal 


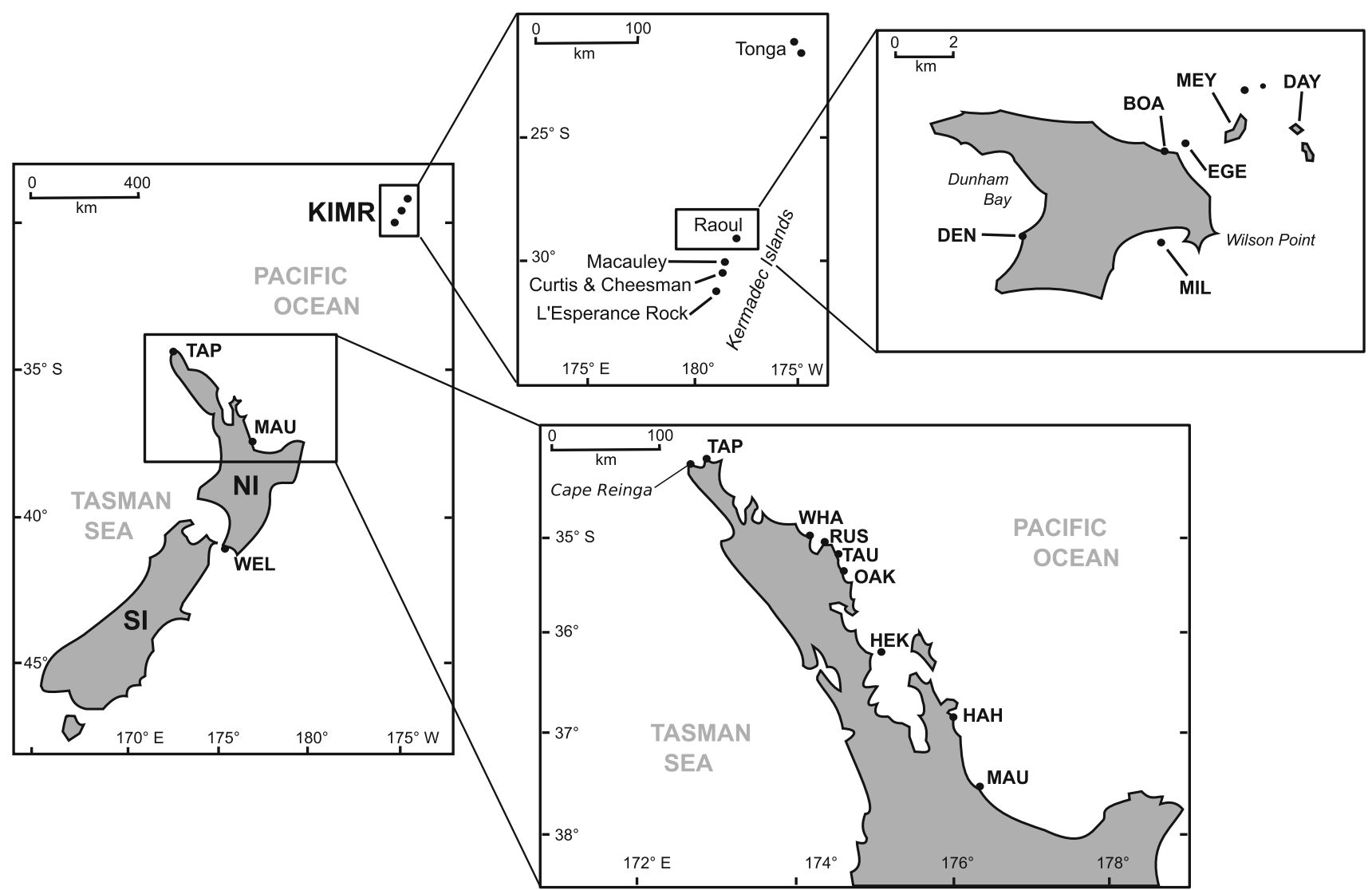

Fig. 1 Map of the sampled area around New Zealand and the Kermadec Islands. NI North Island, SI South Island, KIMR Kermadec Islands Marine Reserve, BOA Boat Landing, DAY Dayrell Island, $D E N$ East Denham, EGE Egeria Islet, $M E Y$ Meyer Island, MIL Milne

and (3) between the Kermadec Islands and the North Island, separated by $750-2,000 \mathrm{~km}$, with no possible stepping stone dispersal over $750 \mathrm{~km}$ of open sea.

\section{Materials and methods}

\section{Sampling area}

The Kermadec Islands is a subtropical island arc in the South Pacific Ocean, composed of 11 volcanic islands and are approximately 0.6-1.4 m years old (Gabites Appendix 2 in Lloyd and Nathan 1981). They are divided into three groups: the northern group with Raoul Island and its outlying islets; the middle group with Curtis, Cheeseman and Macauley Islands; the southern group with L'Esperance Rock and Havre Rock (Gardner et al. 2006).

Sample collection and storage

Samples of N. melanotragus were collected between 2002 and 2006 from the North Island and during two research trips in
Islet, TAP Tapotupotu Bay, WHA Wharau Road, RUS Russell Harbour, TAU Taupiri Bay, OAK Oakura Bay, HEK Waiheke Island, $H A H$ Hahei, MAU Mt Maunganui, WEL Wellington

2002 and 2004 from the Kermadec Islands (Fig. 1). In total, 580 individuals were collected from 15 populations (280 individuals from six populations of the northern group of the Kermadec Islands, and 300 individuals from nine populations of the North Island) (Table 1). Whole animals were sampled and preserved in absolute ethanol after crushing each shell to allow infiltration of the ethanol to the deeper tissues. Samples were subsequently stored in the lab at $4{ }^{\circ} \mathrm{C}$.

\section{DNA extraction}

Each individual was removed from its shell. Genomic DNA was extracted from $\sim 2$ to $4 \mathrm{~mm}^{3}$ of foot tissue, directly under the operculum, using the High Pure PCR Template preparation kit (Roche) following the manufacturer's instructions. Extracted DNA concentration was estimated by running each sample against a High DNA mass ladder (Invitrogen) on an ethidium bromide-stained $1 \%$ agarose gel. DNA was subsequently stored at $-20{ }^{\circ} \mathrm{C}$. We controlled for species identification by amplifying the mitochondrial gene cytochrome oxidase subunit 1 (COI) using the universal primers LCO1490 and HCO2198 
Table 1 Sampling sites where samples were collected, along with the coding used in this chapter (code), number of individuals $(N)$, sites coordinates (geometric latitude and longitude) and the sampling date

\begin{tabular}{|c|c|c|c|c|c|}
\hline Sampled sites & Code & $N$ & Latitude & Longitude & Sampling date \\
\hline \multicolumn{6}{|l|}{ Kermadec Islands } \\
\hline Boat Landing, Raoul Island & BOA & 40 & $29^{\circ} 15.418^{\prime} \mathrm{S}$ & $177^{\circ} 54.140^{\prime} \mathrm{W}$ & $8 / 11 / 04$ \\
\hline Dayrell Island & DAY & 50 & $29^{\circ} 14.407^{\prime} \mathrm{S}$ & $177^{\circ} 51.265^{\prime} \mathrm{W}$ & $11 / 07 / 04$ \\
\hline East Denham Bay, Raoul Island & DEN & 40 & $29^{\circ} 16.396^{\prime} \mathrm{S}$ & $177^{\circ} 57.010^{\prime} \mathrm{W}$ & $4 / 11 / 04$ \\
\hline Egeria Islet & EGE & 50 & $29^{\circ} 14.586^{\prime} \mathrm{S}$ & $177^{\circ} 53.417^{\prime} \mathrm{W}$ & $9 / 07 / 02$ \\
\hline Meyer Island & MEY & 50 & $29^{\circ} 14.405^{\prime} \mathrm{S}$ & $177^{\circ} 52.412^{\prime} \mathrm{W}$ & $7 / 07 / 02$ \\
\hline Milne Islet & MIL & 45 & $29^{\circ} 16.516^{\prime} \mathrm{S}$ & $177^{\circ} 54.146^{\prime} \mathrm{W}$ & $10 / 07 / 02$ \\
\hline \multicolumn{6}{|l|}{ New Zealand North Island } \\
\hline Tapotupotu Bay, Cape Reinga & TAP & 30 & $34^{\circ} 26.530^{\prime} \mathrm{S}$ & $172^{\circ} 42.497^{\prime} \mathrm{E}$ & $23 / 04 / 08$ \\
\hline Wharau Road, Bay of Islands & WHA & 40 & $35^{\circ} 12.352^{\prime} \mathrm{S}$ & $174^{\circ} 02.721^{\prime} \mathrm{E}$ & $3 / 10 / 05$ \\
\hline Russell Harbour, Bay of Islands & RUS & 29 & $35^{\circ} 15.571^{\prime} \mathrm{S}$ & $174^{\circ} 07.195^{\prime} \mathrm{E}$ & $6 / 10 / 05$ \\
\hline Taupiri Bay, Bay of Islands & TAU & 30 & $35^{\circ} 16.427^{\prime} \mathrm{S}$ & $174^{\circ} 17.421^{\prime} \mathrm{E}$ & $6 / 10 / 05$ \\
\hline Oakura Bay, Bay of Islands & OAK & 31 & $35^{\circ} 22.975^{\prime} \mathrm{S}$ & $174^{\circ} 20.890^{\prime} \mathrm{E}$ & $7 / 10 / 05$ \\
\hline Waiheke Island, Hauraki Gulf & HEK & 40 & $36^{\circ} 47.582^{\prime} \mathrm{S}$ & $175^{\circ} 5.458^{\prime} \mathrm{E}$ & $11 / 04 / 09$ \\
\hline Hahei, Coromandel & HAH & 35 & $36^{\circ} 50.231^{\prime} \mathrm{S}$ & $175^{\circ} 48.116^{\prime} \mathrm{E}$ & $27 / 04 / 03$ \\
\hline Mount Maunganui, Bay of Plenty & MAU & 32 & $37^{\circ} 38.279^{\prime} \mathrm{S}$ & $176^{\circ} 11.503^{\prime} \mathrm{E}$ & $24 / 09 / 02$ \\
\hline Wellington, Island Bay & WEL & 32 & $41^{\circ} 20.403^{\prime} \mathrm{S}$ & $174^{\circ} 45.331^{\prime} \mathrm{E}$ & 26/12/06 \\
\hline
\end{tabular}

(Folmer et al. 1994) and analysed the morphology of the operculum as described in Spencer et al. (2007).

\section{Primer amplification and genotyping}

Ten fluorescently labelled microsatellite primer pairs were designed for N. melanotragus (Reisser et al. 2012) and divided into three multiplex groups. Amplifications were carried out on an Applied Biosystems GeneAmp 2700 Thermocycler using a touch-down PCR protocol over 45 cycles: a first initial step of $2 \mathrm{~min}$ at $96^{\circ} \mathrm{C}$ followed by 20 cycles of $20 \mathrm{~s}$ at $94{ }^{\circ} \mathrm{C}, 30 \mathrm{~s}$ at $55^{\circ} \mathrm{C} / 45^{\circ} \mathrm{C}$ (annealing temperature progressively lowered by $0.5^{\circ} \mathrm{C}$ per cycle) and $30 \mathrm{~s}$ at $72{ }^{\circ} \mathrm{C}$, followed by 25 cycles of $20 \mathrm{~s}$ at $94{ }^{\circ} \mathrm{C}$, $30 \mathrm{~s}$ at $45^{\circ} \mathrm{C}$ and $30 \mathrm{~s}$ at $72{ }^{\circ} \mathrm{C}$, followed by a final elongation step of $7 \mathrm{~min}$ at $72{ }^{\circ} \mathrm{C}$. Allele scoring was automated in GeneMarker (SoftGenetics, State College, PA) after the creation of allele binary files specific to each microsatellite marker.

\section{Data analysis}

The goodness of fit of each locus to Hardy-Weinberg equilibrium (HWE) was tested for using GENEPOP'007 (Rousset 2008) and MICRO-CHECKER version 2.2.3 (Van Oosterhout et al. 2004). The data set was divided into four groupings for analyses: (1) all Kermadec Islands populations, (2) all North Island populations, (3) all populations divided in two groups (North Island vs. Kermadec Islands) and (4) all populations taken individually.

\section{Genetic diversity}

Allelic diversity (A), observed $(\mathrm{Ho})$ and expected $\left(\mathrm{H}_{\mathrm{E}}\right)$ heterozygosities under HWE, and the inbreeding coefficient $\left(F_{\text {IS }}\right)$ were estimated using GENEPOP'007 for each of the 15 populations. Tests for linkage disequilibrium were performed in GENEPOP using a likelihood ratio test with a level of significance determined by permutation (Markov Chain parameters: 10,000 dememorization steps, 5,000 batches, 10,000 iterations per batch). Statistical significance ( $P$ values) was corrected for multiple testing using the False Discovery Rate (FDR) procedure (Benjamini and Hotchberg 1995). Allelic richness [Ar(g)] standardised for sample sizes was calculated by HPrare V1.0 (Kalinowski 2005) using a rarefaction method, with the minimum number of genes (g) set by the software to values of 46 (for the North Island populations), 76 (for the Kermadec Islands populations) and 520 (for all 15 populations). The mean $\operatorname{Ar}(\mathrm{g})$ was calculated for each population and then compared across groups using the Mann-Whitney $U$ test (for comparison of 2 samples) or its extension and the Kruskal-Wallis test (3 samples or more) suitable for nonparametric data, as implemented in Statistica (Statsoft 1994).

\section{Population genetic structuring and relationship}

We performed an AMOVA analysis in Arlequin 3.5.1.2 (Excoffier and Lischer 2010) with year of sample collection as one of the variables to test for any structuring effect linked with temporal variation of genotype frequencies. 
Population pairwise $F_{\mathrm{ST}}$ values were also estimated in Arlequin for each of the four geographic groupings, and significance was assessed after 10,000 permutations. Fisher's exact tests of differentiation between pairs of loci were performed in Arlequin (Raymond and Rousset 1995), with 10,000 permutations. Where appropriate, all $P$ values were adjusted using the FDR procedure.

We also took into account recent criticism of the exclusive use of $F_{\mathrm{ST}}$ or $G_{\mathrm{ST}}$ as measures of genetic differentiation (Gerlach et al. 2010; Meirmans and Hedrick 2010). We calculated Jost's estimated $D$ values ( $D_{\text {EST }}$; Jost 2008) using the software SMOGD (Crawford 2010), with 100 bootstrap replicates, and calculated the $D_{\mathrm{EST}}$ harmonic mean across loci for each pairwise population comparison.

\section{Estimation of self-recruitment}

Assignment methods are complementary to $F_{\mathrm{ST}}$ estimates because they provide a specific assessment of contemporary migration, whereas $F_{\mathrm{ST}}$ methods assess average levels of gene flow over long time scales (see Manel et al. 2005 for full discussion). To determine levels of contemporary dispersal and self-recruitment within and between groups, and averaged from all populations between groups, assignment tests were carried out with GENECLASS2 (Piry et al. 2004), employing the "leave one-out" methodology (Paetkau et al. 2004). Probability of assignment was based on 10,000 simulated individuals and an exclusion threshold of $P<0.05$. Individuals that were excluded from their populations of collection were reassigned to another sampled population when $P>0.1$. The difference between the exclusion threshold and the reassignment threshold allows for the presence of individuals originating from non-sampled populations (Underwood et al. 2007). When the results indicated more than one possible population of origin $(P>0.1)$, the individual was assigned to the population showing the highest probability.

\section{Spatial genetic structuring}

Isolation by distance was tested for with a Mantel test, performed by the software ISOLDE, through GENEPOP (online platform). The Mantel test examines the correlation between genetic differentiation (pairwise $F_{\mathrm{ST}}\left(1-F_{\mathrm{ST}}\right)$ values) and geographic location using the logarithm of geographic distances among populations (shortest possible route via the sea).

In order to test for the presence of random, clumped or uniform spatial distributions of alleles, the software package Alleles in Space (AIS; Miller 2005) was employed to perform an allelic aggregation index analysis (AAIA) based on the analysis of individual genotypes (and not alleles despite the name of the analysis) to test non-random patterns of spatial genetic diversity (null hypothesis that genotypes are distributed at random across a landscape; see Clark and Evans 1954, and Miller 2005 for modifications). AIS, rather than implementing methodology that relies on arbitrary groupings of individuals, instead has the ability to perform joint analyses of interindividual spatial and genetic information that can be applied at virtually any spatial scale. Estimation of the "physical area" encompassed by the samples used a rectangle defined by the maximum and minimum coordinates provided in the data set's coordinate file (default option in AIS). This technique is particularly suitable when working on large spatial scale. An allele-specific aggregation index $R_{j}$ was calculated for each allele at each locus and was used to obtain an average allelic aggregation index $R_{\mathrm{j}}^{\mathrm{AVE}}$. Significance of $R_{\mathrm{j}}$ and $R_{\mathrm{j}}^{\mathrm{AVE}}$ was tested through the use of 1,000 permutations.

\section{Results}

Data set analysis

A total of 574 individuals were analysed (299 from the North Island and 275 from the Kermadec Islands). Tests for Hardy-Weinberg equilibrium showed that three loci (Ner15, Ner42 and Ner49) deviated significantly from expectations in almost all of the populations (Table 2). MICRO-CHECKER attributed this deviation to the presence of null alleles and stuttering. These three loci were dropped from all analyses.

\section{Overall genetic diversity}

Rarefied allelic richness ranged from 2.998 to 14.000 with 10 private alleles in the Kermadec Islands populations, from 2 to 12.124 with 15 private alleles for the North Island populations and from 4.952 to 16.786 with 22 private alleles for all populations (15 from North Island and 7 from the Kermadec Islands) (Table 2). No significant linkage disequilibrium was observed for any pairs of loci after FDR correction.

AMOVA analysis testing the effect of the year of sampling (two temporal groups: 2002-2004 vs. 2005-2009) indicated that the percentage of variation between the two time groups was of $0 \%\left(F_{\mathrm{CT}}<0.001\right.$, $P=0.533)$, as was the variation among populations within groups $\left(F_{\mathrm{SC}}<0.001, P=0.929\right)$. The variation among individuals within populations represented $1.31 \%$ of the total variation of the sample set ( $F_{\text {IS }}=0.013, P=0.076$ ). Finally, $98.86 \%$ of the total variation was attributed to differences within individuals $\left(F_{\mathrm{IT}}=0.011, P=0.121\right)$. 


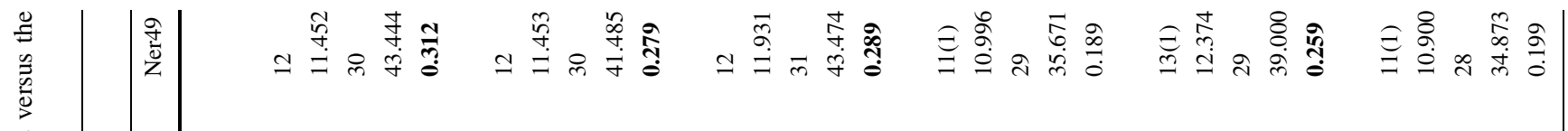

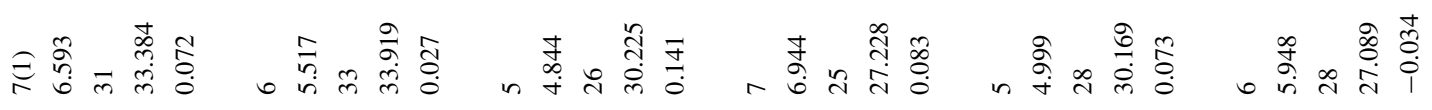

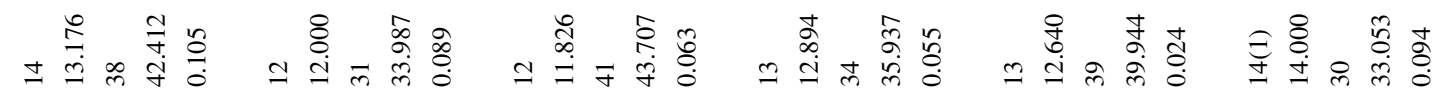

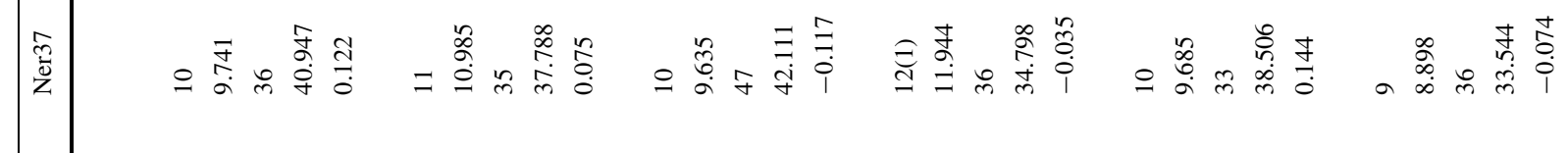

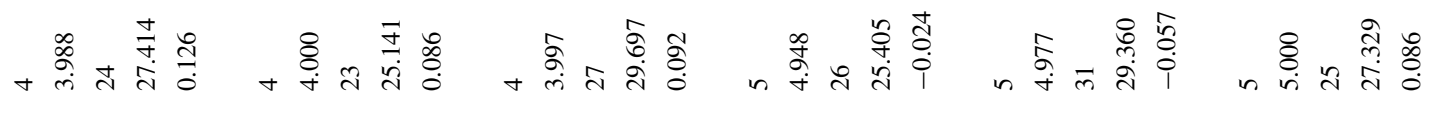

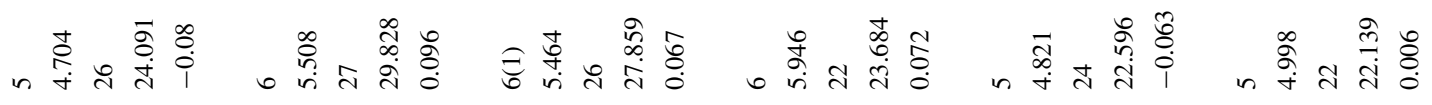

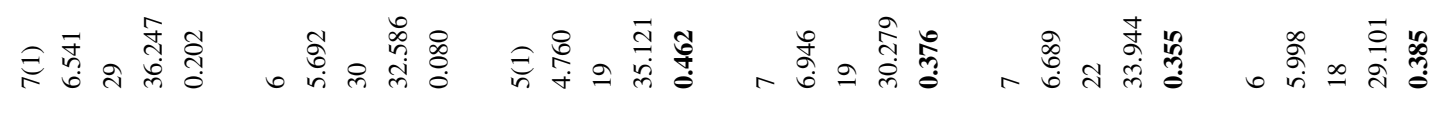

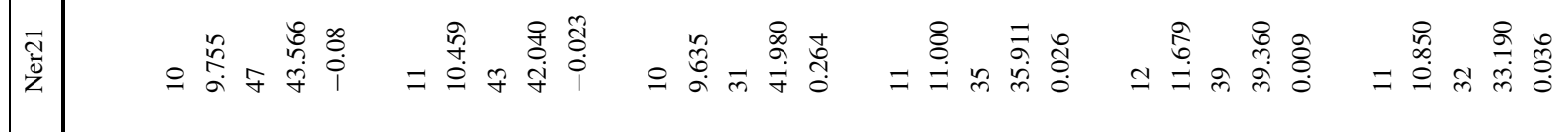$$
0 \ln \pi \frac{\pi}{0}
$$

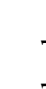




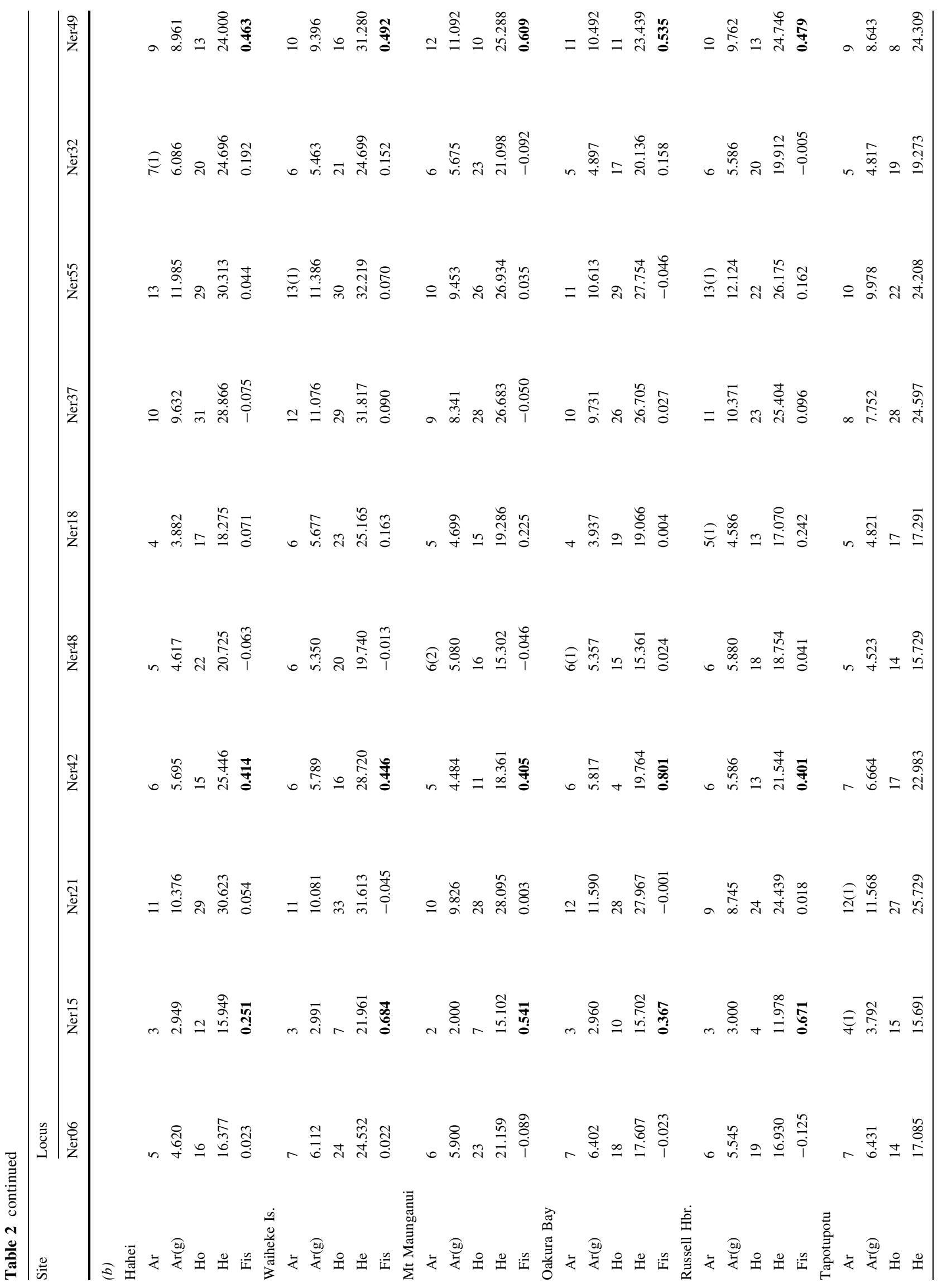




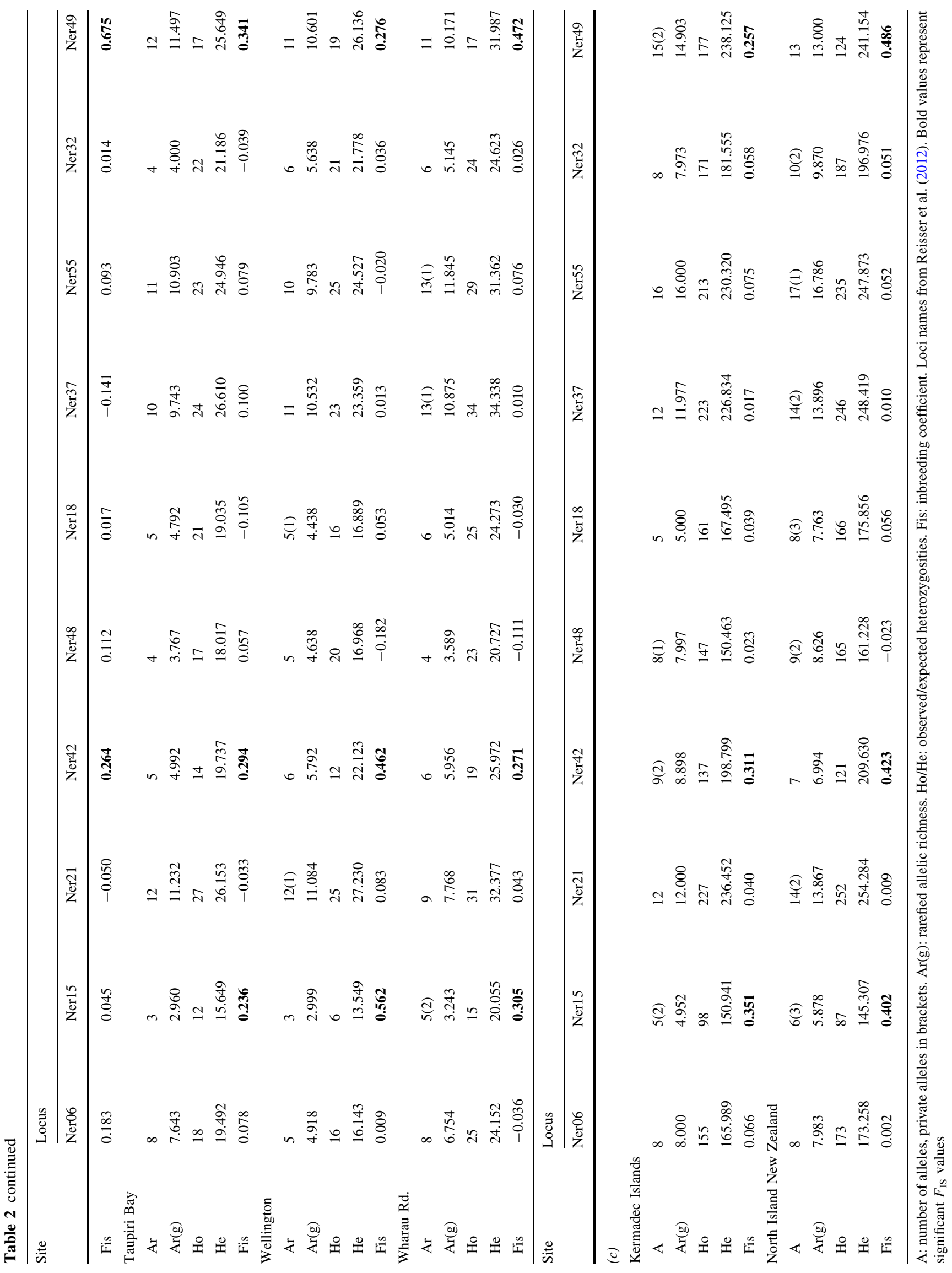


Genetic structuring among the Kermadec Islands populations

Mean rarefied allelic richness calculated over the seven loci revealed no significant difference among the six sampled populations (Kruskal-Wallis, $P=0.416$ ). Estimates of $F_{\mathrm{ST}}$ between pairs of populations within the Kermadec Islands ranged from 0.000 to 0.005 and were not statistically significant, as were Jost's $D_{\mathrm{EST}}$ harmonic means across loci, ranging from 0.000 to 0.004 (Table 3). Fisher's exact tests of differentiation between pairs of populations were not statistically significant $(P>0.999)$. Assignment tests successfully classified 45 individuals to their sampled populations, with assignment success ranging from $7.5 \%$ (East Denham) to $33 \%$ (Milne Islet) (Table 4). A total of 230 individuals were assigned to other populations and three individuals (one from Boat Landing, one from East Denham and one from Meyer Islet) remained unassigned. Isolation by distance analysis revealed no correlation between genetic distance and geographic distance $\left(R^{2}=0.001 ; P=0.526\right)$, and the AAIA analysis showed no significant allelic aggregation within the Kermadec Islands sample set $\left(R_{\mathrm{AVE}}=0.874, P=0.197\right)$.

Genetic structuring among the North Island populations

There was no significant difference in allelic richness among the nine sampled populations (Kruskal-Wallis, $P=0.433$ ). Pairwise $F_{\mathrm{ST}}$ values were not statistically significant and ranged from 0.000 to 0.006 , as were Jost's $D_{\text {EST }}$ harmonic means across loci, ranging from 0.000 to 0.015 (Table 3). Fisher's exact tests of differentiation between pairs of loci confirmed these results $(P>0.999)$. Assignment testing correctly classified 30 out of 297 individuals to their sampled populations, with an assignment success ranging from $0 \%$ (Wellington Coast) to $26.7 \%$ (Taupiri Bay) (Table 4). No individuals remained unassigned. Isolation by distance analysis revealed no correlation between genetic distance and geographic distance $\left(R^{2}=0.0009, P=0.458\right)$ and the AAIA analysis showed no significant allelic aggregation within the North Island sample set $\left(R_{\mathrm{AVE}}=0.751, P=0.303\right)$.

Genetic structuring between the combined North Island populations and the combined Kermadec Islands populations

The Mann-Whitney test did not reveal any significant difference in allelic richness between populations from the combined North Island and the combined Kermadec Islands populations $(P=0.482)$. The $F_{\mathrm{ST}}$ value between the combined Kermadec Islands populations and the combined North Island populations was not significant nor was Jost's $D_{\text {EST }}$ value $(0.000$ and 0.001 , respectively, Table 3). Fisher's exact tests of differentiation also gave non-significant results $(P>0.999)$. A total of 316 individuals were correctly assigned to their sampled geographic group, with a $49.5 \%$ success for the Kermadec Islands populations and $60.5 \%$ success for the North Island populations, and 21 individuals (13 from the North Island and 8 from the Kermadec Islands) remained unassigned (Table 4).

Genetic structuring among all 15 populations

No significant difference in allelic richness was found when considering all the 15 populations independently (Kruskal-Wallis, $P=1.000$ ), and pairwise $F_{\mathrm{ST}}$ estimation and Jost's $D_{\mathrm{EST}}$ harmonic mean across loci ranged from 0.000 to 0.007 and from 0.000 to 0.015 , respectively, and were not significant (Table 3). Fisher's exact tests of differentiation also gave non-significant results $(P>0.999)$. Assignment testing correctly classified 35 out of 570 individuals to their sampled populations, with an assignment success ranging from $0 \%$ (Russell Harbour and Wellington) to $15.21 \%$ (Milne Islet). One individual from East Denham remained unassigned (Table 4). Whilst the isolation by distance analysis showed no correlation between genetic distance and geographic distance $\left(R^{2}=0.001, P=0.172\right)$, the AAIA analysis revealed significant allelic aggregation $\left(R_{\mathrm{AVE}}=0.686, P=0.016\right)$, indicating the non-random occurrence of genotypes across the geographic distribution of all the populations.

\section{Discussion}

Our results provide evidence of high levels of gene flow at scales of $10 \mathrm{~s}$ of $\mathrm{km}$ and also at scales of $100 \mathrm{~s}$ of $\mathrm{km}$ and therefore highlight the "open" nature of genetic connectivity in and between coastal mainland and oceanic island populations.

Genetic homogeneity of $N$. melanotragus populations

The analysis of $N$. melanotragus populations from the Kermadec Islands revealed complete genetic homogeneity across all six populations. This lack of structuring is not surprising given the spatial scale involved and likely results from high migration rates among populations, as reflected by the low $F_{\mathrm{ST}}$ values. This observation is supported by the relatively low assignment success of individuals to their sampled population. This indicates that all populations can be considered as "open" at the scale of the Kermadec Islands archipelago (maximum distance between sites of $14.5 \mathrm{~km}$ ). High levels of migration are likely to be reached 
Table 3 Population pairwise Jost's $D_{\text {EST }}$ values of differentiation (above diagonal) and population pairwise $F_{\mathrm{ST}}$ values (below diagonal) for (a) the Kermadec Islands populations, (b) the New Zealand
North Island populations, (c) the combined Kermadec Islands populations versus the combined New Zealand North Island populations and (d) all 15 populations taken independently

\begin{tabular}{|c|c|c|c|c|c|c|c|c|c|c|c|c|c|}
\hline & & \multicolumn{2}{|c|}{ Dayrell Island } & Meyer Islet & \multicolumn{3}{|c|}{ Egeria Islet } & \multicolumn{2}{|c|}{ Boat Landing } & \multicolumn{2}{|c|}{ Milne Islet } & \multicolumn{2}{|c|}{ East Denham Bay } \\
\hline \multicolumn{14}{|l|}{ (a) } \\
\hline Dayrell Island & \multicolumn{3}{|c|}{-} & 0.001 & \multicolumn{3}{|c|}{0.001} & \multicolumn{2}{|c|}{0.000} & \multicolumn{2}{|l|}{0.000} & \multicolumn{2}{|l|}{0.004} \\
\hline Meyer Islet & \multicolumn{3}{|c|}{0.005} & - & \multicolumn{3}{|c|}{-0.014} & \multicolumn{2}{|c|}{0.000} & \multicolumn{2}{|l|}{0.000} & \multicolumn{2}{|l|}{0.001} \\
\hline Egeria Islet & \multicolumn{3}{|c|}{0.000} & 0.000 & \multicolumn{3}{|c|}{-} & \multicolumn{2}{|c|}{0.001} & \multicolumn{2}{|l|}{0.000} & \multicolumn{2}{|l|}{0.000} \\
\hline Boat Landing & & \multicolumn{2}{|c|}{0.000} & 0.000 & \multicolumn{3}{|c|}{0.000} & \multicolumn{2}{|l|}{-} & \multicolumn{2}{|l|}{0.000} & \multicolumn{2}{|l|}{0.001} \\
\hline Milne Islet & & \multicolumn{2}{|c|}{0.000} & 0.000 & \multicolumn{3}{|c|}{0.000} & \multicolumn{2}{|c|}{0.000} & \multicolumn{2}{|l|}{-} & \multicolumn{2}{|l|}{0.003} \\
\hline \multirow[t]{2}{*}{ East Denham Bay } & & 0.00 & & 0.000 & & 0.000 & & 0.0 & & 0.002 & & - & \\
\hline & Tapotup & potu & Wharau Rd & Russell Hbr & Taupiri & ri Bay & Oakura & Bay & Waiheke Isl. & Hahei & Mt Mau & ganui & Wellington \\
\hline (b) & & & & & & & & & & & & & \\
\hline Tapotupotu & - & & 0.000 & 0.000 & 0.000 & & 0.000 & & 0.000 & 0.000 & 0.000 & & 0.000 \\
\hline Whaurau Rd & 0.000 & & - & 0.000 & 0.000 & & 0.001 & & 0.000 & 0.000 & 0.000 & & 0.001 \\
\hline Russell Hbr & 0.000 & & 0.000 & - & 0.000 & & 0.000 & & 0.000 & 0.000 & 0.000 & & 0.000 \\
\hline Taupiri Bay & 0.000 & & 0.000 & 0.000 & - & & 0.000 & & 0.000 & 0.000 & 0.000 & & 0.000 \\
\hline Oakura Bay & 0.000 & & 0.000 & 0.000 & 0.000 & & - & & 0.000 & 0.000 & 0.000 & & 0.000 \\
\hline Waiheke Isl & 0.000 & & 0.000 & 0.002 & 0.000 & & 0.000 & & - & 0.015 & 0.000 & & 0.000 \\
\hline Hahei & 0.000 & & 0.000 & 0.002 & 0.000 & & 0.000 & & 0.000 & - & 0.000 & & 0.000 \\
\hline Mt Maunganui & 0.000 & & 0.000 & 0.000 & 0.000 & & 0.000 & & 0.000 & 0.000 & - & & 0.000 \\
\hline Wellington & 0.000 & & 0.006 & 0.000 & 0.000 & & 0.000 & & 0.006 & 0.003 & 0.000 & & - \\
\hline
\end{tabular}

$$
\text { North Isl. }
$$

Kermadec Isl.

(c)

North Isl.

$\begin{array}{ll}- & 0.001\end{array}$

Kermadec Isl.

0.000

$-$

Dayrell Isl. $\quad$ Meyer Isl. $\quad$ Egeria Isl. $\quad$ Boat Landing $\quad$ Milne Isl. $\quad$ East Denham $\quad$ Tapotupotu Bay Wharau Rd

\begin{tabular}{|c|c|c|c|c|c|c|c|c|}
\hline & \multicolumn{8}{|c|}{ (d) } \\
\hline Dayrell Isl. & - & 0.001 & 0.001 & 0.000 & 0.000 & 0.004 & 0.000 & 0.000 \\
\hline Meyer Isl. & 0.005 & - & 0.000 & 0.000 & 0.000 & 0.001 & 0.000 & 0.000 \\
\hline Egeria Isl. & 0.000 & 0.000 & - & 0.001 & 0.000 & 0.000 & 0.000 & 0.000 \\
\hline Boat landing & 0.000 & 0.000 & 0.000 & - & 0.000 & 0.001 & 0.000 & 0.006 \\
\hline Milne Isl. & 0.000 & 0.000 & 0.000 & 0.000 & - & 0.003 & 0.000 & 0.001 \\
\hline East Denham & 0.001 & 0.000 & 0.000 & 0.000 & 0.002 & - & 0.000 & 0.002 \\
\hline Tapotupotu & 0.000 & 0.000 & 0.000 & 0.000 & 0.000 & 0.000 & - & 0.000 \\
\hline Wharau Rd & 0.000 & 0.000 & 0.000 & 0.000 & 0.001 & 0.001 & 0.000 & - \\
\hline Russell Hbr & 0.005 & 0.000 & 0.000 & 0.000 & 0.003 & 0.000 & 0.000 & 0.000 \\
\hline Taupiri Bay & 0.000 & 0.000 & 0.000 & 0.000 & 0.000 & 0.000 & 0.000 & 0.000 \\
\hline Oakura Bay & 0.000 & 0.000 & 0.000 & 0.000 & 0.000 & 0.000 & 0.000 & 0.000 \\
\hline Waiheke Isl. & 0.000 & 0.002 & 0.001 & 0.000 & 0.000 & 0.005 & 0.000 & 0.000 \\
\hline Hahei & 0.000 & 0.000 & 0.000 & 0.000 & 0.000 & 0.004 & 0.000 & 0.000 \\
\hline Mt Maunganui & 0.000 & 0.007 & 0.000 & 0.000 & 0.000 & 0.000 & 0.000 & 0.000 \\
\hline \multirow[t]{2}{*}{ Wellington } & 0.007 & 0.003 & 0.000 & 0.000 & 0.002 & 0.000 & 0.000 & 0.006 \\
\hline & Russell Hbr & \multicolumn{2}{|c|}{ Taupiri Bay } & Oakura Bay & Waiheke Isl. & Hahei & Mt Maunganui & Wellington \\
\hline \multicolumn{9}{|l|}{ (d) } \\
\hline Dayrell Isl. & 0.001 & 0.0 & & 0.001 & 0.003 & 0.000 & 0.000 & 0.000 \\
\hline Meyer Isl. & 0.000 & 0.0 & & 0.000 & 0.001 & 0.000 & 0.000 & 0.002 \\
\hline
\end{tabular}


Table 3 continued

\begin{tabular}{|c|c|c|c|c|c|c|c|}
\hline & Russell Hbr & Taupiri Bay & Oakura Bay & Waiheke Isl. & Hahei & Mt Maunganui & Wellington \\
\hline Egeria Isl. & 0.000 & 0.000 & 0.000 & 0.000 & 0.000 & 0.000 & 0.000 \\
\hline Boat landing & 0.000 & 0.000 & 0.000 & 0.003 & 0.000 & 0.002 & 0.000 \\
\hline Milne Isl. & 0.000 & 0.000 & 0.000 & 0.000 & 0.000 & 0.000 & 0.000 \\
\hline East Denham & 0.000 & 0.000 & 0.001 & 0.007 & 0.000 & 0.000 & 0.002 \\
\hline Tapotupotu & 0.000 & 0.000 & 0.000 & 0.000 & 0.000 & 0.000 & 0.000 \\
\hline Wharau Rd & 0.000 & 0.000 & 0.001 & 0.000 & 0.000 & 0.000 & 0.001 \\
\hline Russell Hbr & - & 0.000 & 0.000 & 0.000 & 0.000 & 0.000 & 0.000 \\
\hline Taupiri Bay & 0.000 & - & 0.000 & 0.000 & 0.000 & 0.000 & 0.000 \\
\hline Oakura Bay & 0.000 & 0.000 & - & 0.000 & 0.000 & 0.000 & 0.000 \\
\hline Waiheke Isl. & 0.002 & 0.000 & 0.000 & - & 0.015 & 0.000 & 0.000 \\
\hline Hahei & 0.002 & 0.000 & 0.000 & 0.000 & - & 0.000 & 0.000 \\
\hline Mt Maunganui & 0.000 & 0.000 & 0.000 & 0.000 & 0.000 & - & 0.000 \\
\hline Wellington & 0.000 & 0.000 & 0.000 & 0.006 & 0.003 & 0.000 & - \\
\hline
\end{tabular}

Statistically significant $P$ value after correction for FRD are indicated in boldface

because of the small estimated larval dispersal time required for connecting the different populations. Larvae of $N$. melanotragus can spend an average of 5 months ( $\sim 150$ days) in the water column before either dying or recruiting to a population (Waters et al. 2005, 2007). Sutton et al. (2009) studied the directionality and timing of virtual larval drift in the Kermadec region using oceanographic models and found that drifting larvae dispersed in a roughly circular pattern from each of the Kermadec Islands, with a slight eastward bias introduced by the mean flow. The timing of larval dispersion from Raoul Island (the main island in the northern group) to its neighbouring islands and seamounts averaged 1-3 days and was in the order of 10 days for the most distant islands to the south of the Kermadec archipelago. These dispersal values are small compared to the estimated PLD of $N$. melanotragus and highlight the potential for larvae of this species to disperse among all suitable sites within the Kermadec Islands archipelago. Beyond this, the modelling estimates of flow among islands of the Kermadec Islands group provided by Sutton et al. (2009) result in an intriguing possibility. The minimum PLD of $N$. melanotragus is unknown, but given that the maximum PLD is 5-6 months, it seems likely that larvae of this species must spend more than a few days in the water column to achieve a reasonable state of development and a competent state for settlement. N. atramentosa larvae, the sister species with similar life history, has a minimum PLD of 3 months (in Waters et al. 2005, from Underwood 1974). Thus, if the minimum PLD is greater than 3-4 days (as seems likely), then recruitment of Kermadec-derived individuals to Kermadec sites is unlikely to occur, meaning that all or very nearly all individuals of $N$. melanotragus within the Kermadec Islands are immigrants from the New Zealand North Island, or from other more distant populations.

Genetic investigation of $N$. melanotragus from the North Island of New Zealand also revealed genetic homogeneity among all nine populations. Hence, those populations may also be considered as "open" at the scale of the North Island (i.e. from 14 to $1,100 \mathrm{~km}$ ). These results are congruent with many connectivity studies that have reported high levels of genetic homogeneity associated with extensive gene flow among populations of many different taxa occurring as far south as $41.5^{\circ} \mathrm{S}$, the geographic extent of NZ's North Island (reviewed by Ross et al. 2009; Gardner et al. 2011). Based on modelling of surface currents, estimated dispersal times across the sampled sites in the North Island range from 11 to 144 days (Chiswell and Rickard 2011), the upper limit of which is very similar to the PLD of $N$. melanotragus. Stepping stone dispersal is also expected to play a role in contributing to the lack of genetic structuring. In support of this, no particular directionality in migration was detected in the present study (131 individuals assigned to the south of their sampled populations vs. 136 individuals assigned to the north), despite the presence of a directional current pattern along the east coast of the North Island (the East Auckland Current, EAC, flowing southward; Sutton et al. 2009). Although the EAC is the main oceanographic current of the east coast of NZ, details of the fine-scale oceanographic features of this region are still lacking, and it is likely that local oceanographic features such as eddies will trap larvae and allow them to disperse against the mean flow at a given time and place, allowing for multi-directional dispersal.

There was also an absence of genetic structuring at the largest spatial investigated-across the range of Kermadec 
Table 4 Assignment test results showing percentage of individuals successfully assigned for: (a) the Kermadec Islands populations, (b) the New Zealand North Island populations, (c) the combined
Kermadec Islands populations versus the combined New Zealand North Island populations and (d) all 15 populations taken independently

\begin{tabular}{|c|c|c|c|c|c|c|c|c|c|c|c|}
\hline & \multicolumn{3}{|c|}{ Dayrell Isl. } & Meyer Isl. & \multicolumn{3}{|c|}{ Egeria Isl. } & oat landing & \multicolumn{2}{|c|}{ Milne Isl. } & East Denham \\
\hline \multicolumn{12}{|l|}{ (a) } \\
\hline Dayrell Isl.* & \multicolumn{3}{|c|}{8} & 8 & \multicolumn{3}{|c|}{8} & 36 & \multicolumn{2}{|c|}{32} & 6 \\
\hline Meyer Isl.* & \multicolumn{3}{|c|}{12} & 14 & \multicolumn{3}{|c|}{12} & 12 & \multicolumn{2}{|c|}{40} & 6 \\
\hline Egeria Isl.* & \multicolumn{3}{|c|}{12} & 16 & \multicolumn{3}{|c|}{8} & 20 & \multicolumn{2}{|c|}{34} & 8 \\
\hline Boat landing* & \multicolumn{3}{|c|}{15} & 7.5 & \multicolumn{3}{|c|}{10} & 30 & \multicolumn{2}{|c|}{32.5} & 2.5 \\
\hline Milne Isl. & \multicolumn{3}{|c|}{15.6} & 24.4 & \multicolumn{3}{|c|}{4.4} & 17.8 & \multicolumn{2}{|c|}{33.3} & 4.4 \\
\hline \multirow[t]{2}{*}{ East Denham* } & \multicolumn{3}{|c|}{15} & 10 & \multicolumn{2}{|r|}{20} & \multicolumn{2}{|c|}{20} & 25 & & 7.5 \\
\hline & Tapotuc & otu & Wharau Rd & Russell Hbr & Taupir & ri Bay & Oakura Bay & Waiheke Isl. & Hahei & Mt Maunganui & Wellington \\
\hline (b) & & & & & & & & & & & \\
\hline Tapotupotu* & 13.3 & & 3.3 & 10.0 & 33.3 & & 16.7 & 0.0 & 10.0 & 6.7 & 3.3 \\
\hline Wharau Rd & 0.0 & & 7.5 & 22.5 & 32.5 & & 12.5 & 5.0 & 2.5 & 15.0 & 2.5 \\
\hline Russell Hbr* & 3.4 & & 3.4 & 10.3 & 37.9 & & 13.8 & 3.4 & 6.9 & 13.8 & 3.4 \\
\hline Taupiri Bay & 3.3 & & 0.0 & 13.3 & 26.7 & & 26.7 & 6.7 & 13.3 & 6.7 & 3.3 \\
\hline Oakura Bay & 6.5 & & 0.0 & 19.4 & 19.4 & & 16.1 & 3.2 & 3.2 & 29.0 & 3.2 \\
\hline Waiheke Isl. & 10.0 & & 7.5 & 10.0 & 30.0 & & 15.0 & 7.5 & 5.0 & 15.0 & 0.0 \\
\hline Hahei & 8.6 & & 2.9 & 14.3 & 28.6 & & 14.3 & 0.0 & 5.7 & 20.0 & 5.7 \\
\hline Mt Maunganui & 3.1 & & 3.1 & 15.6 & 28.1 & & 31.3 & 3.1 & 9.4 & 6.3 & 0.0 \\
\hline Wellington & 6.3 & & 0.0 & 18.8 & 25.0 & & 18.8 & 15.6 & 0.0 & 15.6 & 0.0 \\
\hline
\end{tabular}

$$
\text { North Isl. }
$$

Kermadec Isl

(c)

North Isl.

60.5

39.5

Kermadec Isl.

51.5

49.5

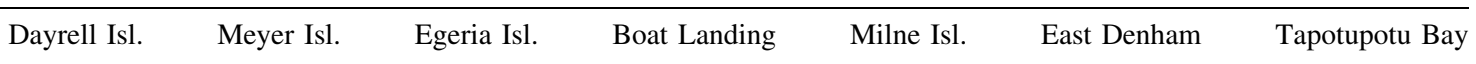

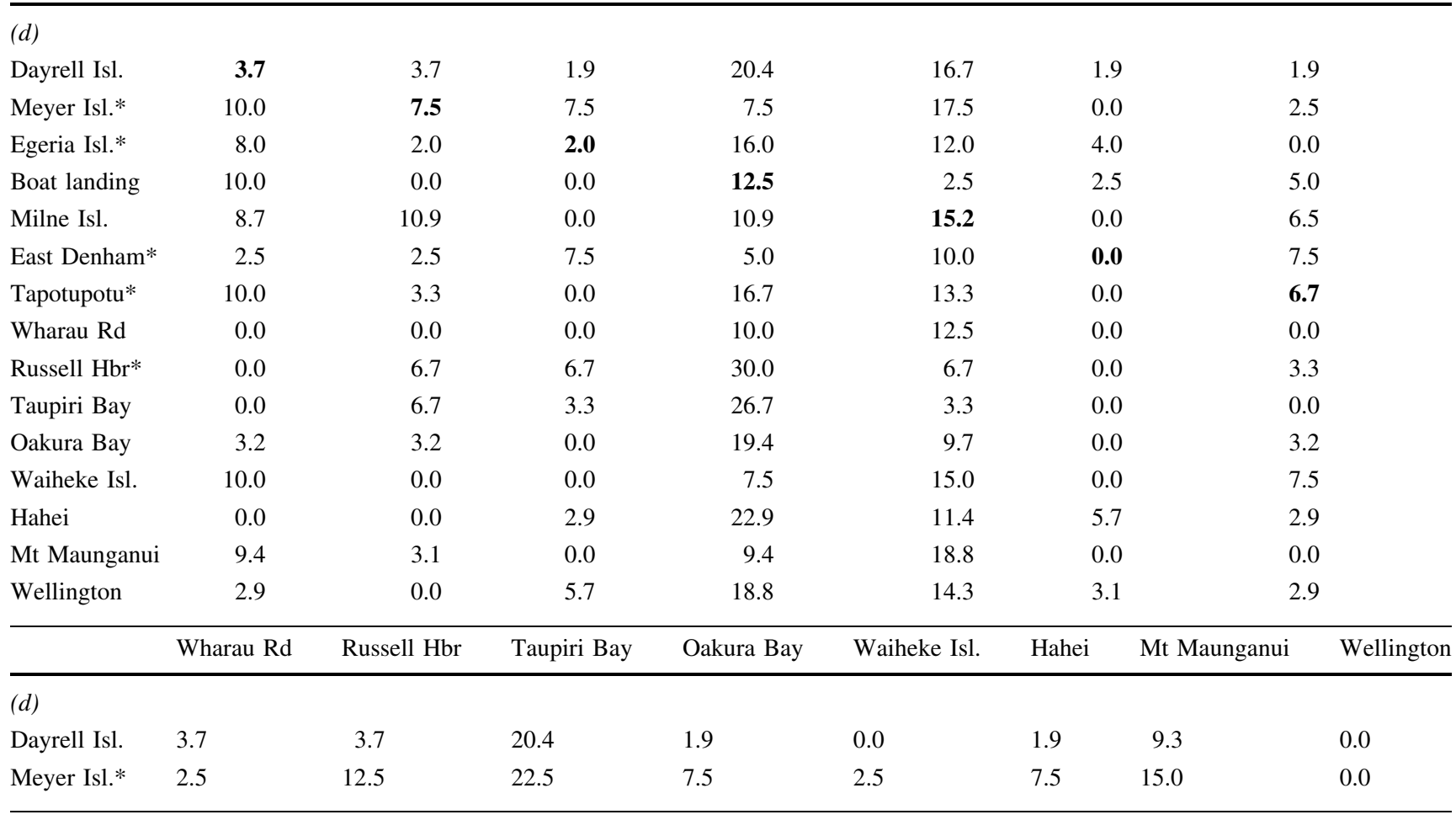


Table 4 continued

\begin{tabular}{|c|c|c|c|c|c|c|c|c|}
\hline & Wharau Rd & Russell Hbr & Taupiri Bay & Oakura Bay & Waiheke Isl. & Hahei & Mt Maunganui & Wellington \\
\hline Egeria Isl.* & 0.0 & 20.0 & 18.0 & 2.0 & 2.0 & 4.0 & 8.0 & 0.0 \\
\hline Boat landing & 2.5 & 12.5 & 17.5 & 15.0 & 0.0 & 5.0 & 0.0 & 2.5 \\
\hline Milne Isl. & 0.0 & 10.9 & 6.5 & 6.5 & 2.2 & 4.3 & 8.7 & 6.5 \\
\hline East Denham* & 0.0 & 15.0 & 27.5 & 2.5 & 2.5 & 5.0 & 5.0 & 0.0 \\
\hline Tapotupotu* & 0.0 & 6.7 & 30.0 & 3.3 & 0.0 & 3.3 & 3.3 & 3.3 \\
\hline Wharau Rd & 5.0 & 15.0 & 32.5 & 7.5 & 5.0 & 0.0 & 12.5 & 0.0 \\
\hline Russell Hbr* & 3.3 & 0.0 & 16.7 & 10.0 & 3.3 & 6.7 & 3.3 & 0.0 \\
\hline Taupiri Bay & 0.0 & 13.3 & 13.3 & 13.3 & 6.7 & 10.0 & 3.3 & 0.0 \\
\hline Oakura Bay & 0.0 & 9.7 & 12.9 & 9.7 & 3.2 & 0.0 & 22.6 & 3.2 \\
\hline Waiheke Isl. & 2.5 & 10.0 & 22.5 & 10.0 & 5.0 & 2.5 & 7.5 & 0.0 \\
\hline Hahei & 0.0 & 5.7 & 20.0 & 8.6 & 0.0 & 2.9 & 14.3 & 0.0 \\
\hline Mt Maunganui & 0.0 & 9.4 & 18.8 & 15.6 & 3.1 & 9.4 & 3.1 & 0.0 \\
\hline Wellington & 9.4 & 8.6 & 18.8 & 8.6 & 3.1 & 0.0 & 9.4 & 0.0 \\
\hline
\end{tabular}

Boldface shows correct assignments. The symbol (*) indicates populations with at least one non-assigned individual

Island North Island populations that are $\sim 750 \mathrm{~km}$ apart. Only the allelic aggregation analysis showed a small but significant difference between the regions, explained by the presence of private alleles ( 7 in the Kermadec Islands and 15 in the North Island populations). Assignment tests revealed that migrants were equally distributed between the two groups, which is indicative of bidirectional exchange across the South Pacific Ocean, consistent with estimations of larval dispersal time from Raoul Island to Cape Reinga and the reverse direction (over 1.5 months, and about 1 month respectively; Sutton et al. 2009). Comparison between the two regions points to the importance of stepping stone dispersal within the North Island group. For example, pairwise comparison of each individual North Island population with each of the Kermadec Islands populations reveals only genetic homogeneity. This extends to the most southerly of the North Island populations which is $\sim 2,000 \mathrm{~km}$ from the Kermadec Islands group: the estimated dispersal time between Wellington and the Kermadec Islands is 180 days, which is slightly longer than the PLD of $N$. melanotragus (based on data in Sutton et al. 2009 and Chiswell and Rickard 2011). The absence of genetic differentiation between populations that are so geographically distinct is best explained by longdistance dispersal between the Kermadec Islands and the New Zealand North Island via a stepping stone model of dispersal that is well developed within the North Island group of populations. Hence, we conclude that the realised dispersal of a $N$. melanotragus larva is at least $750 \mathrm{~km}$ (see Pinsky et al. 2012 for definitions).

Although microsatellite markers have many advantages compared to other techniques (e.g. allozymes, mitochondrial DNA, RAPDs, AFLPs, etc.), they also have limitations for some applications. The stepwise mutation process that adds or subtracts repeats to existing alleles may result in alleles of identical size having different mutational histories. Alleles of identical size but different identities are usually scored as the same allele, thereby reducing the levels of differentiation among populations/individuals. This phenomenon, known as allele size homoplasy, is made more likely if the range of possible allele sizes itself is constrained (Estoup et al. 2002). Many statistical analyses made with microsatellite data are highly affected by homoplasy. For example, genetic indices such as Wright's $F_{\text {ST }}$ estimate (1931), Weir and Cockerham's $\theta\left(F_{\mathrm{ST}}\right)$ estimate or Nei's Ds and Da distances (Nei 1972; Takezaki and Nei 1996) are all based on the infinite allele model (the assumption that mutations generate only new alleles). Homoplasy will therefore result in an underestimation of genetic distance when using those statistics. It is possible that homoplasy occurs in our data set, leading to an overestimation of genetic homogeneity. However, complementary studies using other types of markers can be used to further support or reject hypotheses and observations made with microsatellites. For example, Waters et al. (2007) examined mitochondrial DNA (COI sequence) variation in $N$. melanotragus and reported no evidence of differentiation between populations on either side of the Tasman Sea. In the context of genetic connectivity between NZ and Australia, Chiswell et al. (2003) suggested that such transport would take approximately 700 days, more than 4 times the PLD of $N$. melanotragus. Although infrequent long-distance dispersal events may allow a handful of larvae to travel from Australia to New Zealand, it is more likely that dispersal follows a stepping stone pattern, using two intermediate island groups, Lord Howe Island and Norfolk Island, where N. melanotragus is known to occur. Hence, results obtained on a broader spatial scale and with 
another type of molecular marker are consistent with our own findings, potentially indicating that although homoplasy is possible, it should not play a significant role in levels of genetic homogeneity of our populations.

Long-distance dispersal, environmental tolerance and phenotypic plasticity

Long-distance dispersal may be achieved in different ways, including rafting on natural or man-made objects (Fraser et al. 2011; Hoeksema et al. 2012). Whilst there is presently no evidence for rafting as mechanism of dispersal for $N$. melanotragus, it cannot be discounted for post-metamorphic stages. In terms of larval dispersal, which is the most likely major contributor to long-distance dispersal, the possession of a long PLD suggests that the larvae are likely to experience contrasting environmental conditions in the water column as they are dispersed over long distances and between different regions. It also means that newly arrived recruits at a site may experience very different environmental conditions than those at their natal site. N. melanotragus occurs on rocky intertidal shores across a region encompassing the east coast of Australia, Lord Howe Island, Norfolk Island, northern New Zealand and the Kermadec Islands. These regions range from cool temperate, through warm temperate, to subtropical, with the associated environmental variability inherent in such regional differences. Indeed, the Kermadec Islands biota has been recognised as unique, with a marine environment providing important links between the temperate waters of the coasts of New Zealand and the subtropical and tropical waters of Australia and Fiji and Tonga, respectively (Gardner et al. 2006 and references therein). The high levels of gene flow between the Kermadec Islands and northern New Zealand, coupled with the absence of stepping stone dispersal and transient adaptation/selection, suggest a significant degree of tolerance to environmental variation in the larvae, juveniles and adults of $N$. melanotragus. It seems likely that selection for broad-ranging phenotypic plasticity is an adaptation and possibly even a requirement associated with the possession of a larval phase with a long PLD when dispersal may encompass a range of environmental conditions.

Crandall et al. (2010) reported high levels of connectivity in two amphidromous gastropods in the Caribbean, and although they attributed this genetic homogeneity to the long PLD of these species, they noted that larvae occurring in a "rare habitat" could display acute phenotypic plasticity (time of metamorphosis) in order to optimise their chances of settling successfully. Indeed, two conflicting selection pressures act on the dispersal capacity of larvae occurring in rare or remote habitats: (1) selection might favour homing/retention behaviours in order for a maximum number of larvae to self-recruit (Strathmann et al. 2002) and (2) selection might favour physiologic or developmental traits allowing for plasticity in term of settlement time (Elkin and Marshall 2007, in Crandall et al. 2010). For N. melanotragus, it seems likely that in addition to plasticity in settlement time, physiologic traits might also allow for plasticity in settlement location (i.e. capacity to adapt to a wide range of environmental conditions). This would account for the ability of the Kermadec Islands larvae to settle in New Zealand populations (and vice versa), as well as trans-Tasman exchange between Australia and NZ, and explains the wide-ranging ecological distribution of this species.

Acknowledgments We thank the New Zealand Department of Conservation for the sampling permits (issued to JPAG), and Ann R Wood for help with sample collection. We thank the ABI sequencing and genotyping services of Massey University, and particularly Richard Fong and Lorraine Berry for precious advice on sample quality. We are grateful to Peter Ritchie and Elizabeth Heeg for statistical assistance. We also thank two anonymous reviewers for their helpful comments on this manuscript. This research was supported by funding from the Centre for Marine Environmental and Economic Research of Victoria University of Wellington (New Zealand) and by a Victoria University of Wellington Ph. D. scholarship to Céline M.O. Reisser.

Conflict of interest The authors declare no conflict of interest.

\section{References}

Almany GR, Berumen ML, Thorrols SR, Planes S, Jones GP (2007) Local replenishment of coral reef fish populations in a marine reserve. Science 316:742-744

Bell JJ, Okamura B (2005) Low genetic diversity in a marine reserve: re-evaluating diversity criteria in reserve design. Proc Natl Acad Sci USA 272:1067-1074

Benjamini Y, Hochberg Y (1995) Controlling the false discovery rate: a practical and powerful approach to multiple testing. J Roy Statist Soc Ser B 57:289-300

Chiswell SM, Rickard GJ (2011) Larval connectivity of harbours via ocean currents: a New Zealand study. Cont Shelf Res 31:1057-1074

Chiswell SM, Wilkin J, Booth JD, Stanton B (2003) Trans-Tasman sea-larval transport: is Australia a source for New Zealand rock lobsters? Mar Ecol Prog Ser 247:173-182

Clark PJ, Evans FC (1954) Distance to nearest neighbor as a measure of spatial relationships in populations. Ecology 35:445-453

Cowen RK, Lwiza KMM, Sponaugle S, Paris CB, Olson DB (2000) Connectivity of marine populations: open or closed? Science 287:857-859

Cowen RK, Sponaugle S (2009) Larval dispersal and marine population connectivity. Ann Rev Mar Sci 1:443-466

Crandall ED, Taffel JR, Barber PH (2010) High gene flow due to pelagic larval dispersal among South Pacific archipelagos in two amphidromous gastropods (Neritomorpha: Neritidae). Heredity 104:563-572

Crandall ED, Treml EA, Barber PH (2012) Coalescent and biophysical models of stepping stone gene flow in Neritid snails. Mol Ecol 21:5579-5598 
Crawford NG (2010) SMOGD: software for the measurement of genetic diversity. Mol Ecol Resour 10:556-557

Elkin C, Marshall DJ (2007) Desperate larvae: influence of deferred costs and habitat requirements on habitat selection. Mar Ecol Prog Ser 335:143-153

Estoup A, Jarne P, Cornuet JM (2002) Homoplasy and mutation model at microsatellite loci and their consequences for population genetics analysis. Mol Ecol 11:1591-1604

Excoffier L, Lischer L (2010) Arlequin suite ver 3.5): A new series of programs to perform population genetics analyses under Linux and Windows. Mol Ecol Resour 10:564-567

Fraser CI, Nikula R, Waters JM (2011) Oceanic rafting by a coastal community. Proc R Soc B 278:649-655

Frey MA, Vermeij GJ (2008) Molecular phylogenies and historical biogeography of a circumpolar group of gastropods (genus: Nerita): implications for regional diversity patterns in the marine tropics. Mol Phylogenet Evol 48:1067-1086

Gardner JPA, Curwen M, Long J, Williamson RJ, Wood AR (2006) Benthic community structure and water column characteristics in the Kermadec Islands Marine Reserve, New Zealand. NZ J Mar Freshw Res 40:179-194

Gardner JPA, Bell JJ, Constable HB, Hannan D, Ritchie PA, Zuccarello GC (2011) Multi-species coastal marine connectivity: a literature review with recommendations for further research. New Zealand Aquatic Environment and Biodiversity Report No. 58

Gerlach G, Jueterbock A, Kraemer P, Deppermann J, Harmand P (2010) Calculations of population differentiation based on $G_{S T}$ and $\mathrm{D}$ : forget $\mathrm{G}_{\mathrm{ST}}$ but not all of statistics! Mol Ecol 19:3845-3852

Hilbish TJ, Deaton LE, Koehn RK (1982) Effect of an allozyme polymorphism on regulation of cell volume. Nature 298:688-689

Hoeksema BW, Roos PJ, Cadée GC (2012) Trans-Atlantic rafting by the brooding reef coral Favia fragum on man-made flotsam. Mar Ecol Prog Ser 445:209-218

Johnson M, Black R (2006) Islands increase genetic subdivision and disrupt patterns of connectivity of intertidal snails in a complex archipelago. Evolution 60:2498-2506

Jost L (2008) $\mathrm{G}_{\mathrm{ST}}$ and its relatives do not measure differentiation. Mol Ecol 17:4015-4026

Kalinowski ST (2005) HP-RARE 1.0: a computer program for performing rarefaction on measures of allelic richness. Mol Ecol Notes 5:187-189

Koehn RK, Newell RIE, Immermann F (1980) Maintenance of an aminopeptidase allele frequency cline by natural selection. Proc Natl Acad Sci USA 77:5385-5389

Lloyd EF, Nathan S (1981) Geology and tephrochronology of Raoul Island, Kermadec Group, New Zealand. NZ Geol Surv Bull 95:1-105

Manel S, Gaggioti OE, Waples RS (2005) Assignment methods: matching biological questions with appropriate techniques. Trends Ecol Evol 20:136-142

Meirmans PG, Hedrick PW (2010) Assessing population structure: $F$ st and other related measures. Mol. Ecol Resour 11:5-18

Miller MP (2005) Alleles In Space (AIS): computer software for the joint analysis of inter-individual spatial and genetic information. J Hered 96:722-724

Morgan SA (1995) Life and death in the plankton: larval mortality and adaptation. In: McEdwards L (ed) Ecology of marine invertebrate larvae. CRC Press, New York

Nei M (1972) Genetic distance between populations. Am Nat 106:283-292

Nunes F, Norris RD, Knowlton N (2009) Implications of isolation and low genetic diversity in peripheral populations of an amphiatlantic coral. Mol Ecol 21:4283-4297
Paetkau D, Slade R, Burden M, Estoup A (2004) Genetic assignment methods for the direct, real-time estimation of migration rate: a simulation-based exploration of accuracy and power. Mol Ecol 13:55-65

Pineda J, Hare JA, Sponaugle S (2008) Larval transport and dispersal in the coastal ocean and consequences for population connectivity. Oceanography 20:22-39

Pinsky ML, Palumbi SR, Andréfouêt S, Purkis SJ (2012) Open and closed seascapes: where does habitat patchiness create populations with high fractions of self recruitment? Ecol Appl 22:1257-1267

Piry S, Alapetite A, Cornuet J-M, Paetkau D, Baudouin L, Estoup A (2004) GeneClass2: a software for genetic assignment and firstgeneration migrant detection. J Hered 95:536-539

Raymond M, Rousset F (1995) An exact test for population differentiation. Evolution 49:1280-1283

Reisser CMO, Bell JJ, Wood AR, Gardner JPA (2011) Connectivity, small islands and large distances: the Cellana strigilis limpet complex in the Southern Ocean. Mol Ecol 20:3399-3413

Reisser CMO, Bell JJ, Gardner JPA (2012) Isolation and characterization of polymorphic microsatellite markers for the intertidal sea snail Nerita melanotragus E.A. Smith, 1884 (Powell 1979). Mol Ecol Resour 12:570-572

Ross PM, Hogg ID, Pilditch C, Lundquist CJ (2009) Phylogeography of new Zealand's coastal benthos. NZ J Mar Freshw Res 43:1009-1027

Rousset F (2008) GENEPOP'007: a complete re-implementation of the GENEPOP software for Windows and Linux. Mol Ecol Resour 8:103-106

Scheltema RS (1986) On dispersal and planktonic larvae of benthic invertebrates: an eclectic overview and summary of problems. Bull Mar Sci 39:290-322

Shanks AL (2009) Pelagic larval duration and dispersal distance revisited. Bio Bull 216:373-385

Statsoft (1994) Statistica for Windows manuals. Statsoft, Tulsa

Strathmann RR, Hughes TP, Kuris AM, Lindeman KC, Morgan SG, Pandolfi JM, Warner RR (2002) Evolution of local recruitment and its consequences for marine populations. Bull Mar Sci 70:377-396

Sutton P, Chiswell S, Gorman R, Kennan S, Rickard G (2009) Physical marine environment of the Kermadec Islands region. Unpublished report prepared for the Department of Conservation, Wellington

Swearer S, Caselle J, Lea D, Warner RR (1999) Larval retention and recruitment in an island population of a coral-reef fish. Nature 402:799-802

Takezaki N, Nei M (1996) Genetic distances and reconstruction of phylogenetic trees from microsatellite DNA. Genetics 144:389-399

Tracey ML, Bellet NF, Gravem CD (1975) Excess allozyme homozygosity and breeding population structure in the mussel Mytilus californianus. Mar Biol 32:303-311

Underwood AJ (1974) The reproductive cycles of and geographical distribution of some common eastern Australian prosobranchs Mollusca: Gastropoda). Australas J Mar Freshw Res 25:63-88

Underwood JN, Smith LD, van Oppen MJH, Gilmour JP (2007) Multiple scales of genetic connectivity in a brooding coral on isolated reefs following catastrophic bleaching. Mol Ecol 16:771-784

Van Oosterhout CV, Hutchinson WF, Wills DPM, Shipley P (2004) MICRO-CHECKER: software for identifying and correcting genotyping errors in microsatellite data. Mol Ecol Notes 4:535-538

Waters JM, King TM, O'Loughlin PM, Spencer HG (2005) Phylogeographical disjunction in abundant high-dispersal littoral gastropods. Mol Ecol 14:2789-2802 
Waters JM, McCulloch GA, Eason JA (2007) Marine biogeographical structure in two highly dispersive gastropods: implications for trans-Tasman dispersal. J Biogeogr 34:678-687

Weersing K, Toonen RJ (2009) Population genetics, larval dispersal, and connectivity in marine systems. Mar Ecol Prog Ser 393:1-12

Wei K, Wood AR, Gardner JPA (2013) Population genetic variation in the New Zealand greenshell mussel: locus-dependent conflicting signals of weak structure and high gene flow balanced against pronounced structure and high self-recruitment. Mar Biol 160:931-949
Weir BS, Cockerham CC (1984) Estimating F-Statistics for the analysis of population structure. Evolution 38:1358-1370

Wood AR, Gardner JPA (2007) Small spatial scale population genetic structure in two limpet species endemic to the Kermadec Islands, New Zealand. Mar Ecol Prog Ser 349:159-170

Wright S (1931) Evolution in Mendelian populations. Genetics 16:97-159 